\title{
Ağız ve Diş Sağlığı Merkezinde Örgütsel Bağlılık Analizi: Nicel Bir Araştırma
}

\section{Organizational Commitment Analysis in Oral and Dental Health Center: A Quantitative Research}

\author{
Murat $\mathrm{Ak}^{\mathrm{a}, *}$ \\ ${ }^{a}$ Dr. Öğr. Üyesi, Karamanoğlu Mehmetbey Üniversitesi, Uygulamalı Bilimler Yüksekokulu, Yönetim Bilişim Sistemleri Bölümü, Karaman / Türkiye.
} ORCID: 0000-0003-2292-1444

\section{MAKALE BILGİSI}

\section{Makale Geçmiși:}

Başvuru tarihi: 22 Eylül 2018

Düzeltme tarihi: 16 Ekim 2018

Kabul tarihi: 21 Kasım 2018

\section{Anahtar Kelimeler:}

Örgütsel Bağlılık

Kamu Sağlık Sektörü

Yeniden Yapılandırılan Sağlık Bakanlığı

Ağız ve Diş Sağlığı Merkezi

\section{ARTICLE INFO}

\section{Article history:}

Received 22 September 2018

Received in revised form 16 October 2018

Accepted 21 Nopvember 2018

\section{Keywords:}

Organizational Commitment

Public Health Sector

Ministry of Health Restructured

Oral and Dental Health Center

\section{ÖZ}

Ülkemiz kamu sektörünün en önemli organizasyonlarından biri olan Sağlık Bakanlığı'nda da son yıllarda yeniden yapılanma çalışmaları gündeme gelmektedir. En son 15082017 tarih ve 694 sayılı kanun hükmünde kararname ile yeniden yapılandırılan Sağlık Bakanlığı teşkilat yapısında önemli ve köklü değişiklikler gerçekleştirilmiştir. Bu çalışmada yeniden yapılandırılan Sağlık Bakanlığı'nda tüm örgütler için son derece önemli bir konu olan örgütsel bağlılığın analizinin yapılması hedeflenmektedir. Bu amaçla bu çalışmada Bartın Ağız ve Diş Sağlığı Merkezi evreninde gerçekleştirilen örgütsel bağlılık anketinden elde edilen bulgulara yer verilmektedir. Gerçekleştirilen anket uygulaması sonucunda ağız ve diş sağlığı merkezinde görev yapan kamu çalıșanlarında örgütsel bağl1l1k, duygusal bağl1lıkta 3,46 , devam bağl1lığında 3,38 , normatif bağl1lıkta ise 3,31 seviyesinde gerçekleşmektedir.

\section{Giriş}

Örgütlerin gelişebilmesi ve hedeflerine ulaşabilmesi için çalışanları büyük rol oynamaktadır. Çalışanların örgütlerine karşı geliştirdikleri aidiyet hissi ve adanmışlık duygusu şeklinde tanımlanabilecek örgütsel bağlılık, yönetim ve davranış bilimlerinin en önemli konu başlıklarından birini oluşturmaktadır. Öyle ki örgütsel bağlılık konusu, ilk ortaya atılışından bu yana güncelliğini sürekli koruyarak günümüze kadar gelmiş ve mevcut örgütsel ve bireysel gelişmeler ve değişiklikler göz önüne alındığında önümüzdeki süreçlerde de önemini hiç kaybetmeden koruyacağı anlaşılmaktadır. Hem çalışanları, hem örgütleri çok boyutlu ve kapsamlı etkileyebilme ve yönlendirebilme gücüne sahip olan örgütsel bağlılık, tüm örgütleri ve çalışanları yakından ilgilendirmektedir. Örgütsel bağlılık konusu, her ne kadar ülkemiz kamu sektöründe yöneticiler ve yasa yapıcılar tarafından hak ettiği değeri ve önemi görememiş olsa da kamu kurum ve kuruluşlarında örgütsel bağlılık analizlerinin devam ettiği görülmektedir. Özellikle Türkiye'de son yıllarda değişim ve dönüşüm sürecine giren kamu sektöründe örgütsel bağlılı̆̆ı önemi bir kez daha artmaktadır. Nitekim ülkemiz kamu sektöründe de değişim ve dönüşüm çalışmaları, daha çok kamu hizmetlerinin etkinliğini ve verimliliğini daha fazla geliştirme amacıyla

* Sorumlu yazar/Corresponding author.

e-posta: efe_2288@hotmail.com 
gerçekleştirilmektedir. Bu kapsamda anahtar kavramlardan biri de şüphesiz örgütsel bağl1lık olmaktadır.

Grusky (1966), örgütsel bağlılık konusunda ilk tanımlamayı gerçekleştiren bilim adamlarından biridir. Grusky, örgütsel bağlılığ 1 , çalışanın örgütüne karşı geliştirdiği bağın seviyesi şeklinde tanımlamaktadır (Wahn, 1998: 256). Örgütsel bağlılık, kavram olarak soyut ve psikolojik nitelikler taşımaktadır. Dolayısıyla bağlılık, fiziksel, elle tutulabilen, gözle görülebilen bir kavram değildir. Bağlılık, çalışanın kendi iç dünyasında örgütüne karşı içselleştirdiği duygu ve algılardan oluşmaktadır. Söz konusu bu duygu ve algılar; çalışan için örgütüne karşı bir aidiyet hissi oluşturmakta ve kendi içerisinde seviyelendirilmektedir. Seviyenin güçlü veya zayıf olması, bağlılığın gücünü belirlerken, taşıdığı nitelikler ve biçimsel özellikler ise boyutunu tayin etmektedir. Çalışmada örgütsel bağlılığın boyutlarına değinilmekte ve açıklanmaktadır. Ülkemiz kamu sektörünün en önemli organizasyonlarından biri olan Sağlık Bakanlığı, en son 15.08.2017 tarih ve 694 sayılı Kanun Hükmünde Kararname ile yeniden yapılandırılmış ve teşkilat yapısında önemli ve köklü değişiklikler gerçekleştirilmiştir. Teşkilat yapısında gerçekleştirilen değişiklikler, tüm kamu sağlık teşkilatını yakından etkilemektedir. Bununla birlikte Kamu Sağlık Teşkilatı'nda yer alan sağlık kurum ve kuruluşlarının insan kaynakları, yasal dayanakları ve örgütsel yapıları, birbirlerinden farklı nitelik ve unsurlar taşımaktadırlar. Dolayısıyla söz konusu yapısal değişikliklerden, her kurum veya kuruluş çalışanının; kurumsal yapıların, misyonların, fonksiyonların ve işgücü niteliklerinin farklılıkları sebebiyle farklı ölçüde ve seviyelerde etkilenebilmesi kuvvetle ihtimal dahilindedir. $\mathrm{Bu}$ nedenle bilimsel araştırmaların ve analizlerin, kurum ve kuruluşlar kapsamında, müstakil ve bağımsız çalışmalar ile farklı örneklemler oluşturularak uygulanması, çok daha özel, etkin, nitelikli ve kapsamlı bulguların elde edilmesi için faydalı olabilir. Bu amaçla, bu çalışmada ağız ve diş sağlığı merkezinde uygulanan örgütsel bağl1lık anketi sonucunda elde edilen analiz sonuçlarına yer verilmektedir. Çalışmada uygulanan örgütsel bağlılık anketi, Meyer ve Allen tarafından 1991 yılında gerçekleştirilmiş ve geçerlilik ve güvenirlilik analizleri yapılmıştır. Bartın A ğız ve Diş Sağlığı Merkezi evreninde 51 kadın ve 40 erkek olmak üzere toplam 91 kamu çalışanı bulunmaktadır. Bunlardan 70 çalışana anketin uygulanması arzu edilmiş fakat 47 çalışandan olumlu cevap alınabilmiştir. Bu bağlamda çalışmada anket uygulamasından elde edilen bulgulardan hareketle, Sağlık Bakanlığı'nın yeni teşkilat yapısında çalışanların örgütsel bağlılıklarının kurumsal bazda hangi seviyede bulunduğu ile ilgili analiz sonuçlarına yer verilmektedir. Çalışmada örgütsel bağlılık kavramına teorik olarak değinildikten sonra çalışmanın metodolojisi kısmına geçilmektedir. Bu kısımda; çalışmanın yöntemi ve analizi, çalışmanın evreni ve sınırlılıkları, çalışmanın modeli, çalışmanın güvenirlik analizi, çalışmanın hipotezleri, örgütsel bağlılık ölçeği maddelerine verilen cevapların dağılımı, örgütsel bağlılık ölçeği tanımlayıcı istatistikleri, örgütsel bağlılığın duygusal devam ve normatif bağlılık boyutlarının demografik değişkenlere ve çalışmanın hipotezlerine göre analizine yer verilmektedir. En sonda ise sonuç ve kaynakça kısmı bulunmaktadır.

\section{Ağız ve Diş Sağlığı Merkezleri}

Ağız ve diş sağlığı merkezleri, Türkiye'de sağlık Bakanlığı'na bağlı kurum olmakla birlikte örgütsel yapısı ve insan kaynakları itibariyle diğer sağlık kurum ve kuruluşlarından ayrışmaktadır. Nitekim 13.01.1983 tarih ve 17927 nolu Resmi Gazete'de yayınlanan Yataklı Tedavi Kurumları İşletme Yönetmeliği'nin 3. Maddesinde Ağız ve Diş Sağlığı Merkezleri "Diş hekimliğinin tüm branşlarında koruyucu ve tedavi edici sağlık hizmetleri ile ayaktan veya gerektiğinde yatarak muayene, tetkik, teşhis ve tedavi hizmetlerinin yanı sıra ileri tetkik ve tedavilerin de uygulandığı, en az 10 ünit kapasiteli, idari ve mali bakımdan kendilerine bağlı diş tedavi ve protez merkezleri ile diş poliklinikleri de açılabilen müstakil sağlık kurumlarıdır" şeklinde tanımlanmaktadır. Ağzı ve diş sağlı̆̆ı merkezlerinde sadece ağız ve diş sağlığı hizmetleri verilmektedir. Bunun dışında başkaca bir sağlık hizmeti verilmemekte bu bağlamda ağız ve diş sağlı̆̆ı merkezlerinde salt ağız ve diş sağlığı hizmeti vermek üzere sadece diş hekimleri, diş teknisyen ve teknikerleri, hemşireler, diş protez laborantları ve teknisyenleri görev yapmaktadır. Bu bağlamda, bu çalışmada örgütsel bağlılığın, ağız ve diş sağlığı merkezlerinin ayırıcı örgütsel yapısı ile birlikte insan kaynaklarının farklı işlevsel özellikleri, görevleri, unvanları ve nitelikleri baz alınarak müstakil ve spesifik bir çalışma ile analiz edilmesi daha yararlı ve efektif bulunmaktadır.

\section{3. Örgütsel Bağlılık Kavramı ve Literatür}

Örgütsel bağlılık, örgüt ve işgören için ifade ettiği anlamsal zenginlik ile kapsamlı bir kavramdır. Yazında gerçekleştirilen pek çok çalışmada bu zenginliği görmek mümkündür. Bu kapsamda Kanter (1968), örgütsel bağl1lığ1, işgörenlerin emeklerini ve gayretlerini sosyal bir yapıya adamaya arzulu olmaları, talep ve beklentilerini karşılayacak sosyal bağlar ile kimliklerini birleştirmeleri olarak tanımlamaktadır (Kanter, 1968). Dolayısıyla bağlılık kavramı, soyut ve psikolojik bir görünüm arz etmektedir. Çalışanlar, örgüt ile kendi aralarında psikolojik bir bağ kurmakta, kurulan bu bağı doğuran özellikler ve nitelikler ise bağlılığın şekillenmesinde ve boyutlanmasında rol oynamaktadır.

Aktay (2010) ise örgütsel bağlılığı, çalışanın örgütü için çalışmaya çok arzulu olması ve örgüt üyeliğini sürdürmek için üst seviyede çaba ve efor harcaması şeklinde ifade etmektedir (Aktay, 2010: 25-26). Nitekim bağlılık kavramsal olarak bir aidiyet hissini bünyesinde taşımaktadır. Bir canlıya veya bir olguya karşı hissedilen aidiyet duygusu şeklinde tanımlanabilecek bağlılık kavramı, çalışanlar için örgütlerine aidiyet anlamı taşımaktadır. $\mathrm{Bu}$ kapsamda çalışan, örgütünü önemsemekte onun için mücadele etmeye, çaba harcamaya arzulu ve gönüllü olmaktadır. Benzer şekilde örgütte kalmayı sürdürebilmek, üyeliğini devam ettirebilmek için çalışan yüksek bir performans ve gayret harcamaktadır. Çalışanlarda bu duygu ve davranışları oluşturan ve fiiliyata geçiren olgu ise örgütsel bağlılığ tanımlamaktadır.

Örgütsel bağlılık, genelde bir işgörenin onayı ve psikolojik bir iş akdi sonucunda örgüte katılmasıyla başlamaktadır. Sonrasında ise çalışanın, organizasyonun bir mensubu olarak iş süreçleri, amaçlar, uygulamalar konusunda tutum ve alg1 kazanmasıyla şekillenmektedir (İnce ve Gül, 2005: 1). Dolayısıyla örgütsel bağlılığın gelişmesinde bireyin gönüllü 
olmasının önemli bir rolü bulunmaktadır. Zorlama veya dışardan bir müdahale ile bağlılığın geliştirilmesi mümkün değildir. Bir işgören için örgüte katılma yazılı bir iş sözleşmesi ile mümkün olurken, bağlılığın ortaya çıkabilmesi için de bir nevi psikolojik sözleşme yapılmaktadır. Çalışan, örgütün kendisine sunduğu şartlar ve prosedürler sonucunda kendisinin bireysel tutum ve algılarını biçimlendirmekte ve karşılıklı bir psikolojik sözleşme taraflarca onaylanmaktadır. Böylelikle çalışanın örgütüne karşı geliştirdiği bağlılık boyutu da şekillenmektedir. .

\section{4. Örgütsel Bağglılığın Alt Boyutları}

Örgütler ve çalışanlar için son derece önemli bir kavram olan örgütsel bağlılık, halen güncelliğini korumaktadır. Nitekim sürekli değişim ve gelişim süreçlerinin hakim olduğu modern hayatta, örgütlerin ve bireylerin de bu süreçlerden etkilenmemesi mümkün gözükmemektedir. Örgütsel bağlılık konusu da bu kapsamda güncelliğini hiç kaybetmeyecek yönetim ve davranış bilimlerinin en önemli konu başlıklarından birini oluşturmaktadır. Oldukça geniş ve çok kapsamlı bir konu olan örgütsel bağlılık, bu çalışmada ise Meyer ve Allen'in geliştirdikleri düşünce kapsamında, duygusal, devam ve normatif bağlılık olmak üzere üç alt boyutta değerlendirilmektedir (Meyer ve Allen, 1997:11). Nitekim bu çalışmada kullanılan anket uygulaması da söz konusu boyutları içermektedir.

\subsection{Duygusal Bağlllık}

Duygusal bağlılık, işgörenin örgütüne duygusal olarak yakınlaşmasını, örgütüyle kaynaşmasını, örgütsel hedef ve değerleri içselleştirmesini ve örgüt yararına en üst seviyede emek harcamasını ifade etmektedir (Yüceler, 2009). Duygusal bağlılıkta esas olan çalışanın hissi tutum ve algılamaları olmaktadır. Nitekim duygusal bağlılıkta çalışan için örgütünün manevi bir anlamı ve değeri bulunmaktadır. Çalışan örgütüne karşı bağlılık taşırken pragmatist veya oportunist bir anlayışla hareket etmemektedir. Duygusal bağlılıkta çalışan için örgütüne ahde vefa duyguları, kendisini örgütüne adama ve örgütüyle kendisini özdeşleştirme söz konusu olmaktadır. Böylelikle çalışan örgütü için elinden gelenin daha fazlasını harcamaya çalışmakta, performansını, etkinliğini ve verimliliğini sürekli geliştirmeyi hedeflemektedir. Dolayısıyla örgütler, çalışanlarda duygusal bağlılığın gelişmesini daha fazla istemekte ve önemsemektedirler. Nitekim duygusal bağlılığın daha fazla geliştiği bir örgüt ortamında, örgütsel hedeflere daha hızlı ve kolay ulaşılması söz konusu olabilecektir.

\subsection{Devam Bağl11 $\breve{g ̆}_{1}$}

Obeng ve Ugboro (2003), devam bağlılı̆̆ını, işgörenlerin işletmelerinde bulundukları zaman dilimi içerisinde harcadıkları çaba, emek ve zaman sonucunda kazandıkları sosyal ve mali hakları, statü ve tecrübeyi, işletmelerinden ayrılmaları durumunda kaybedeceklerini düşünmeleri sonucunda gelişen bağlılık olarak tanımlamaktadır (Obeng ve Ugboro, 2003:84).Her çalışan, örgüte katılmasından itibaren belirli bir zaman geçirmekte, çaba harcamakta ve performans sergilemektedir. Bunun sonucunda ise çalışanlar tecrübe, birikim, işi ile ilgili bir takım bilgiler ve yetenekler kazanmaktadırlar. Hatta söz konusu bu kazanımlarının sonucunda, ücret, prim gibi mali haklarının yanında sosyal ve kültürel hakları da şekillenmekte ve süreklilik kazanabilmektedir. Çalışan karşısına farklı bir iș alternatifi çıkması durumunda veya böyle bir arayışa girmesi halinde mevcut kazanımlarını ve birikimlerini göz önüne almak durumundadır. $\mathrm{Bu}$ bağlamda söz konusu potansiyel işin sağlayacağı mali, sosyal ve kültürel getiriler, mevcut işinden daha fazla ve etkin olması durumunda çalışan için fursat maliyeti avantajı ortaya çıkacak ve işinden ayrılmayı göze alabilecektir. Aksi durumda ise çalışan için firsat maliyeti dezavantaj olarak belirecek ve mevcut işini sürdürmek daha avantajlı bir duruma gelecektir. Böylelikle çalışanın, işletmesinde kalmasının daha rasyonel bir karar olacağının ortaya çıkması ile gelişen bağlılık boyutu, devam bağlılığı olarak tanımlanmaktadır.

\subsection{Normatif Bağlll1k}

Normatif bağlılık, işgörenlerin bir takım manevi ve soyut ödül ve faydalar karşılığında, bireysel olarak kendilerini örgütlerine adadıkları bir nevi alışveriş ilişkisini yansitmaktadır (Mowday vd., 1979:225). Normatif bağlılıkta, tutumsal bir aidiyet söz konusu olmaktadır. Çalışan, örgütüne karşı bağlılık geliştirmeyi adeta bir görev veya sorumluluk olarak kabul etmektedir. Çalışanın geliştirdiği bu bağlılık sonucunda, bireysel tatmin ve memnuniyet hisleri oluşmakta ve çalışan, kendisini mutlu hissetmektedir. Normatif bağlılığa sahip çalışanlarda aldığı ücreti hak etme, örgütüne karşı sorumluluk ve görevlerini yerine getirme duyguları baskın ve güçlüdür. Örgütler için duygusal bağlılıktan sonra normatif bağlılık, en çok arzu edilen bağlılık boyutlarından birini oluşturmaktadır. Nitekim normatif bağlılığa sahip çalışanlar, kendilerinden beklenilen performansı ve gayreti sarf etmeye arzulu olacaklar, örgüt faydası ve çıkarları için çalışmayı bir görev, önemli bir sorumluluk olarak kabulleneceklerdir. Örgütler için söz konusu bu durum, pozitif bir eylem sürecini tanımlamaktadır.

Örgütsel bağlılık ile ilgili literatürde çok sayıda çalışmadan söz etmek mümkündür. Kısa bir değerlendirme yapılması durumunda, öncelikle Durukan, Akyürek ve Coşkun tarafından gerçekleştirilen "Hacettepe Üniversitesi Erişkin Hastanesi'nde Çalışan Hemşirelerin Örgütsel Güven, Güçlendirme ve Bağlılık Düzeylerinin Belirlenmesi" isimli çalışmadan bahsedilebilir. Söz konusu çalışmada hemşirelerin örgütsel güven ve güçlendirme seviyeleri ile birlikte bağlılık düzeyleri de kapsamlı olarak değerlendirilmektedir. İlgili çalışmada hemşirelerin bağlılık seviyeleri, ortalama 2,86 seviyesinde belirlenmiş olup sosyodemografik özelliklere göre önemli bir seviyede farklılık tespit edilememiştir (Durukan vd., 2010). Söz konusu çalışmada bağlılık için elde edilen ortalama değerin, bu çalışmada elde edilen ortalama değerlere oranla düşük seviyede gerçekleşmesi dikkat çekmektedir. Bununla birlikte ilgili araştırmanın bu çalışmanın aksine bir üniversite hastanesinde gerçekleştirilmiş olması önem taşımaktadır. Yıldız tarafından literatüre kazandırılan "Örgütsel Bağlılık İle Örgütsel Sinizm ve Örgütsel Muhalefet Arasındaki İlişki”, isimli çalışmada ise bağlılık konusunun, sinizm ve muhalefet arasındaki ilişkisi, istatistiki olarak analiz edilmekte ve yorumlanmaktadır. Bu kapsamda öğretmenlerin bağlıkları ile sinizm ve muhalefet algıları arasında bir ilişkinin mevcut olduğu sonucu ortaya konulmaktadır (Yıldız, 2013). Karahan (2008) tarafindan gerçekleştirilen "Hastanelerde 
Liderlik ve Örgütsel Bağlılık Arasındaki İlișkinin İncelenmesi" isimli çalışmada ise Afyonkarahisar Devlet Hastanesi'nde toplam 321 sağllk personeli üzerinde gerçekleştirilen anket uygulamasından elde edilen sonuçlara değinilmektedir. Bu kapsamda söz konusu çalışmada liderlik ile çalıșanların bağlılıkları arasındaki ilișkilerin anlamlı olduğu, liderlik olgusunun sağlık çalışanlarının bağlılığına pozitif yönde etki yaptığı sonucuna ulaşıldığ 1 ifade edilmektedir (Karahan, 2008).

\section{Metodoloji}

Çalışmanın metodolojisi kapsamında; çalışmanın yöntemi ve verilerin analizi, çalışmanın evreni ve sınırlılıkları, çalışmanın modeli, çalışmanın güvenirlik analizi, çalışmanın hipotezleri, katılımcılara ait demografik bilgilerin dağ 11 mı, örgütsel bağll1ık ölçeği maddelerine verilen cevapların dağılımı, örgütsel bağlılık ölçeği tanımlayıcı istatistikleri ve örgütsel bağll1ı̆̆ın duygusal, devam ve normatif boyutlarının demografik değişkenlere ve hipotezlere göre analizi aşağıda değerlendirilmektedir.

\section{1. Çalışmanın Yöntemi ve Verilerin Analizi}

15082017 tarih ve 694 sayılı Kanun Hükmünde Kararname ile yeniden yapılandırılan Kamu Sağlık Teşkilatı'ndaki mevcut sağlık kurum ve kuruluşlarının beşeri sermayesi ve kurumsal yapıları, birbirlerinden farklı nitelik, misyon, amaç ve yapısal özelliklere sahip bulunmaktadırlar. Bu nedenle akademik çalışmaların, bilhassa sağlık kurum ve kuruluşları nezdinde müstakil ve münferit araştırmalar ile gerçekleştirilmesi, daha özel, etkin, nitelikli ve yararlı bulguların ortaya konulması için faydalı ve gerekli olabilir. Bu kapsamda, bu çalışmada ağız ve diş sağ lığı merkezinde çalışan kamu çalışanlarının örgütsel bağlılık konusundaki algılarının anket ve istatistiki analiz yoluyla değerlendirilmesi amaçlanmaktadır. Bu bağlamda kolayda örnekleme modeli ile çalışanlara anket uygulanmıştır.

Örgütsel bağl1lık ölçeği için Meyer ve Allen tarafindan 1991 yılında gerçekleştirilen örgütsel bağlılık anketinden yararlanılmıştır. Söz konusu örgütsel bağllılı ölçeğinde üç alt boyut olan duygusal, devam ve normatif olarak adlandırılan alt ölçekler, ölçeğin orijinalinde verilen madde dağılımına göre her bir katılımcı için hesaplanmış ve güvenirlik analizleri yapılmıştır. Yapılan analizler, SPSS 20.0 yazılımı ile $\% 95$ güven aralığında gerçekleştirilmiştir.

Örgütsel bağlılık ölçeği alt boyutlarının, iki kategorili değişkenler ile arasında anlamlı fark olup olmadığı bağımsız gruplarda $t$ testi ile incelenmiştir. İkiden fazla grup içeren değişkenlerin grupları arasında anlamlı fark olup olmadığ 1 ise tek yönlü varyans analizi (Anova) ile incelenmiştir. Tek yönlü varyans analizi sonucunda anlamlı fark çıkması durumunda farklılı̆ıın hangi gruptan kaynaklandığını tespit etmek amacıyla TUKEY testi uygulanmıştır. Ölçek ve alt boyutlarının güvenirlik düzeylerinin belirlenmesi için güvenirlik analizi yapılmış ve chronbach alfa katsayısı elde edilmiştir.

Çalışmada, iki tip ölçme aracı (anket) kullanılmaktadır. Bunlar:

(i) Kişisel Bilgi Formu: Ölçme araçları hakkında açıklayıcı kısa bir bilgi ile araştırmaya katılanlar hakkında bilgi toplamak amaciyla oluşturulan formdur. $\mathrm{Bu}$ ölçme aracında kamu personeli ve yöneticilerinin cinsiyeti, yaşı, medeni durumu, öğrenim durumu, kadro durumunu içeren sorular bulunmaktadır.

(ii) Örgütsel Bağllllk Anketi: Örgütsel bağll11k anketi için oluşturulan sorular değerlendirildiğinde aşağıda belirtilen soruların sırasıyla örgütsel bağllı̆ı̆ın duygusal, devam ve normatif bağlılık alt boyutlarını oluşturduğu sonucuna varılmıştır. (Meyer ve Allen, 1991). Böylelikle çalışmada örgütsel bağlllık ölçeği maddeleri, duygusal, devam ve normatif bağll11k boyutları olmak üzere üç boyutta analiz edilmekte ve değerlendirilmektedir.

Ölçme aracı, 1 "Hiç Katılmıyorum", 2 "Katılmıyorum", 3 "Kararsızım", 4 "Katıliyorum" ve 5 "Tamamen Katılıyorum" şeklinde beşli likert tipi bir derecelendirme niteliğini taşımaktadır. $\mathrm{Bu}$ kapsamda düzenlenen anket formları, kolayda örnekleme modeli tercih edilerek ağız ve diş sağlığ merkezi çalışanlarına yöneltilmiştir. Anket uygulaması sonucunda 26 kadın ve 21 erkek personelden geri dönüş sağlanabilmiştir. Böylece toplam 47 personele anketin uygulanması sağlanmıştır.

\section{2. Çalışmanın Evreni ve Sınırlılıkları}

15082017 tarih ve 694 sayılı Kanun Hükmünde Kararname ile yeniden yapılandırılan Kamu Sağlık Teşkilatı'ndaki mevcut sağlık kurum ve kuruluşlarının beşeri sermayesi ve kurumsal yapıları, birbirlerinden farklı nitelik, misyon, amaç ve yapısal özelliklere sahip bulunmaktadırlar. Bu nedenle akademik çalışmaların, bilhassa sağlık kurum ve kuruluşları nezdinde müstakil ve münferit araştırmalar ile gerçekleştirilmesi, daha özel, etkin, nitelikli ve yararlı bulguların bilim dünyasına kazandırılması için faydalı ve gerekli olabilir. Bu bağlamda, bu çalışmanın evrenini, Barın Ağız ve Diş Sağlığı Merkezi'nde görev yapan 51 kadın ve 40 erkekten oluşan toplam 91 personel oluşturmaktadır. Toplam 91 personelden kolayda örnekleme metoduyla 70 personele anket uygulamasının gerçekleştirilmesi arzu edilmiş fakat bunlardan 47'sinden olumlu geri dönüş sağlanabilmiştir. Çalışma kapsamındaki sağlık tesislerine ilişkin veriler, ağız ve diş sağlığı merkezi özlük işleri biriminden elde edilmiştir. Çalışmanın bir takım kısıtları bulunmaktadır. Öncelikle çalışma, yalnızca bir ildeki bir sağlık merkezindeki sağlı personeli üzerinde gerçekleştirilmektedir Değişik ortamlarda ve illerde uygulanacak benzer nitelikteki çalışmalar, değişik sonuçların elde edilmesini sağlayabilir. İkinci olarak çalışma için kullanılan verilerin, ağız ve diş sağlığı merkezinde halen görevini sürdürmekte olan kamu personelinden sağlanması nedeniyle, uygulamada kamu ve özel sağlık kurumları çalışanları arasında bir ayrım yapılamamıştır. Sağlık personeli üzerinde gerçekleştirilecek farklı çalışmaların, kamu kurumlarının kendi arasında ve özel kurumlar ile karşılaştırmalı olarak değerlendirilmesi, konunun değişik bakış açılarıyla analiz edilerek incelenmesini sağlayabilir.

\section{3. Çalışmanın Modeli}

Ağız ve diş sağlığı merkezi bünyesinde çalışan kamu personelinin, örgütsel bağlllık konusunda tutum ve hislerini ölçerek analiz edilmesi amacıyla kolayda örnekleme modeli tercih edilerek anket uygulaması gerçekleştirilmiştir. 


\section{4. Çalışmanın Güvenirlik Analizi}

Çalışmada kullanılan örgütsel bağlılık ölçeği ve alt boyutlarının güvenilirlik düzeyinin belirlenmesi için güvenilirlik analizi yapılmış ve chronbach alfa katsayısı elde edilmiştir.

Tablo 1. Örgütsel Bağlılığın Duygusal, Devam ve Normatif Bağlılık Boyutlarının Chronbach Alfa Katsayısına Göre Değişimi

\begin{tabular}{lcc}
\hline & Madde Sayıs1 & Cronbach's Alpha \\
\hline Örgütsel Bağ l1lık & 17 & 0,836 \\
\hline Duygusal bağl1lık & 6 & 0,923 \\
\hline Devam bağl1lı̆̆ & 6 & 0,805 \\
\hline Normatif bağl1lık & 5 & 0,792 \\
\hline
\end{tabular}

\section{5. Çalışmanın Hipotezleri}

Araştırmanın amacı doğrultusunda aşağıdaki hipotezler geliştirilmiştir:
H1: Ağız ve diş sağlığı merkezi çalışanlarının örgütsel bağlılık boyutları ile cinsiyet değişkeni arasında bir farklılık bulunmaktadır.

H2: Ağız ve diş sağlığg merkezi çalışanlarının örgütsel bağlılık boyutları ile yaş değişkeni arasında bir farklılık bulunmaktadır.

H3: Ağız ve diş sağlığı merkezi çalışanlarının örgütsel bağlılık boyutları ile medeni durum değişkeni arasında bir farklılık bulunmaktadır.

H4: Ağız ve diş sağlığı merkezi çalışanlarının örgütsel bağlılık boyutları ile eğitim değişkeni arasında bir farklılık bulunmaktadır.

\section{6. Örgütsel Bağll1ık Ölçeği Maddelerine Verilen Cevapların Dağılımı}

Örgütsel bağlılık ölçeği maddelerine verilen cevapların dağılımı, frekans analizi ile incelenmiş ve Tablo 2'de verilmektedir.

Tablo 2. Örgütsel Bağlılık Ölçeği Maddelerine Verilen Cevapların Dağılımı

\begin{tabular}{|c|c|c|c|c|c|c|c|c|c|c|}
\hline & \multicolumn{2}{|c|}{$\begin{array}{c}\text { Hiç } \\
\text { Katılmıyorum } \\
\end{array}$} & \multicolumn{2}{|c|}{ Katılmıyorum } & \multicolumn{3}{|c|}{ Kararsızım } & \multicolumn{2}{|l|}{ Katıliyorum } & \multirow{2}{*}{$\begin{array}{c}\text { Kesinlikle } \\
\text { Kat1liyorum } \\
\%\end{array}$} \\
\hline & $\mathrm{n}$ & $\%$ & $\mathrm{n}$ & $\%$ & $\mathrm{n}$ & $\%$ & $\mathrm{n}$ & $\%$ & $\mathrm{n}$ & \\
\hline $\begin{array}{l}\text { Kariyer hayatımın geri kalanını bu kurumda geçirmekten } \\
\text { mutluluk duyarım }\end{array}$ & 5 & 10,6 & 8 & 17,0 & 11 & 23,4 & 13 & 27,7 & 10 & 21,3 \\
\hline $\begin{array}{l}\text { Çalıștı̆̆ım kurumun problemlerini kendi problemlerim gibi } \\
\text { hissediyorum }\end{array}$ & 1 & 2,1 & 2 & 4,3 & 7 & 14,9 & 25 & 53,2 & 12 & 25,5 \\
\hline Bu kurumda kendimi "ailenin bir parçası" gibi hissediyorum & 5 & 10,6 & 6 & 12,8 & 12 & 25,5 & 17 & 36,2 & 7 & 14,9 \\
\hline Bu kuruma karşı duygusal bir bağ hissediyorum & 4 & 8,5 & 11 & 23,4 & 8 & 17,0 & 19 & 40,4 & 5 & 10,6 \\
\hline $\begin{array}{l}\text { Çalıştığım kuruma karşı güçlü bir aidiyet duygusu } \\
\text { hissediyorum }\end{array}$ & 1 & 2,1 & 10 & 21,3 & 8 & 17,0 & 20 & 42,6 & 8 & 17,0 \\
\hline $\begin{array}{l}\text { Çalıştı̆̆ım kurumdan, dışarıdaki insanlara gururla } \\
\text { bahsediyorum }\end{array}$ & 4 & 8,5 & 8 & 17,0 & 5 & 10,6 & 22 & 46,8 & 8 & 17,0 \\
\hline $\begin{array}{l}\text { Şu an bu kurumdan ayrilmam, bundan sonraki hayatımda } \\
\text { maddi zarara uğramama neden olur }\end{array}$ & 4 & 8,5 & 11 & 23,4 & 5 & 10,6 & 15 & 31,9 & 12 & 25,5 \\
\hline Şu an bu kurumda kalmam, istekten ziyade gerekliliktir & 2 & 4,3 & 9 & 19,1 & 5 & 10,6 & 22 & 46,8 & 9 & 19,1 \\
\hline $\begin{array}{l}\text { Bu kurumdan ayrılmayı düşünmek için çok az seçim hakkına } \\
\text { sahip olduğuma inanıyorum }\end{array}$ & 5 & 10,6 & 8 & 17,0 & 9 & 19,1 & 17 & 36,2 & 8 & 17,0 \\
\hline $\begin{array}{l}\text { Benim için bu kurumdan ayrılmanın olumsuz sonuçlarından } \\
\text { biri de başka bir kurumun burada sahip olduğum olanakları } \\
\text { sağlayamama ihtimalidir }\end{array}$ & 3 & 6,4 & 7 & 14,9 & 14 & 29,8 & 17 & 36,2 & 6 & 12,8 \\
\hline $\begin{array}{l}\text { Başka bir iş ayarlamadan bu kurumdan ayrıldığımda neler } \\
\text { olacağı konusunda endișe hissediyorum }\end{array}$ & 4 & 8,5 & 8 & 17,0 & 8 & 17,0 & 18 & 38,3 & 9 & 19,1 \\
\hline $\begin{array}{l}\text { Bu kurumda çalışmaya devam etmemin önemli } \\
\text { nedenlerinden biri de ayrılmamın kişisel fedakarlık } \\
\text { gerektirmesidir }\end{array}$ & 8 & 17,0 & 5 & 10,6 & 9 & 19,1 & 19 & 40,4 & 6 & 12,8 \\
\hline $\begin{array}{l}\text { Benim avantajıma olsa bile çalıştığım kurumdan şimdi } \\
\text { ayrılmak bana doğru gelmiyor. }\end{array}$ & 4 & 8,5 & 2 & 4,3 & 8 & 17,0 & 25 & 53,2 & 8 & 17,0 \\
\hline Bu kurum benim sadakatimi hak ediyor & 4 & 8,5 & 5 & 10,6 & 14 & 29,8 & 16 & 34,0 & 8 & 17,0 \\
\hline $\begin{array}{l}\text { Bu kurumdan şimdi ayrılmamın, burada çalışan diğer } \\
\text { insanlara karşı duyduğum sorumluluklar nedeniyle yanlış } \\
\text { olacağını düşünüyorum }\end{array}$ & 5 & 10,6 & 7 & 14,9 & 13 & 27,7 & 15 & 31,9 & 7 & 14,9 \\
\hline Çalıştığım kuruma çok şey borçluyum & 6 & 12,8 & 5 & 10,6 & 15 & 31,9 & 14 & 29,8 & 7 & 14,9 \\
\hline Bu kurumdan şimdi ayrilırsam, suçluluk hissederim & 9 & 19,1 & 8 & 17,0 & 14 & 29,8 & 7 & 14,9 & 9 & 19,1 \\
\hline
\end{tabular}

\section{7. Örgütsel Bağl1lık Ölçeği Tanımlayıcı İstatistikleri}

Tablo 3'te ağız ve diş sağlığı merkezi genelinde ankete katılım sağlayan çalışanların örgütsel bağlılık anketi ortalamalarının oluşturduğu üç alt boyut için tanımlayıcı istatistikler verilmektedir.

Buna göre ağız ve diş sağlığı merkezi çalışanlarının duygusal bağlılık alt boyutu 1-5 aralığında ortalama 3,46 olarak görülürken, devam bağlılığı alt boyutu ortalama 3,38, normatif bağlılık alt boyutu ortalaması ise 3,31 seviyesinde gerçekleşmiştir. Bu bağlamda Ağız ve Diş Sağlığı Merkezi genelinde örgütsel bağlılık, en yüksek 3,46 ortalama ile duygusal bağlilık boyutunda gerçekleşmiştir. Söz konusu bu oran, 5'li likert ölçeği seviyelendirmesinde yer alan "4 katılıyorum" önermesine yakın bir orandır. Bu bağlamda ağız ve diş sağlığı merkezinde örgütsel bağlılığın daha çok duygusal bağlılık yönünde geliştiği anlaşılmaktadır. 
Duygusal bağlılık, daha çok çalışanların tüm benlikleri ve hisleriyle kendilerini örgütlerine adamasına dayanan, arzuya ve şevke dayalı güçlü bir bağlılıktır. Daha çok hissi saiklere bağlı olduğundan kurumlar için cazip gelmektedir. Bu nedenle örgütlerin çalışanlarda bulunmasını en fazla arzuladıkları bağlılık boyutu, duygusal bağlılık olmaktadır. Duygusal bağlılığın, özel sektör işletmelerinde olduğu gibi kamu kurum ve kuruluşlarında da güçlü olması büyük önem arz etmektedir. Nitekim yüksek duygusal bağlılığa sahip kamu çalışanları, kamunun sunduğu hizmetlerin standardının yükselmesinde, kalitesinin artmasında etkin ve aktif bir misyon üstlenebileceklerdir. Bu bağlamda ağız ve diş sağlığı merkezi bünyesinde görev yapan kamu çalışanlarında duygusal bağlılık alt boyutunun yüksek olması, olumlu bir görünüm olarak değerlendirilebilir.

Tablo 3. Örgütsel Bağlılık Boyutları Duygusal, Devam ve Normatif Bağlılık Alt Boyutlarına İlişkin Tanımlayıcı İstatistikler

\begin{tabular}{lccccc}
\hline & N & Min & Max & Ortalama & Std. Sapma \\
\hline Duygusal Bağlılık & 47 & 1,67 & 5,00 & 3,46 & 0,91 \\
\hline Devam Bağl1lığ1 & 47 & 1,00 & 5,00 & 3,38 & 0,88 \\
\hline Normatif Bağl11ık & 47 & 1,00 & 5,00 & 3,31 & 0,96 \\
\hline
\end{tabular}

\section{8. Örgütsel Bağlılı̆̆ın Duygusal Devam ve} Normatif Bağlılık Boyutlarının Demografik Değişkenlere ve Çalışmanın Hipotezlerine Göre Analizi

Örgütsel bağlılık ölçeğinin alt boyutları olan duygusal, devam ve normatif bağlılık, demografik kriterlere göre değişim gösterebilmektedir. Bu bağlamda aşağıda cinsiyet, yaş, medeni durum, eğitim seviyesi parametreleri bağlamında, duygusal, devam ve normatif bağl1lık şeklinde ele alınan örgütsel bağlılık boyutlarının, çalışmanın hipotezlerine ve demografik kriterlere göre değişimi analiz edilmekte ve değerlendirilmektedir.

\subsubsection{Cinsiyet}

Ağız ve diş sağlığı merkezinde örgütsel bağlılık ölçeği alt boyutlarının, cinsiyete göre ortalamaları ve bu ortalamalar arasındaki farkın anlamlı olup olmadığının tespiti için bağımsız gruplarda t testi uygulanmıştır. Gerçekleştirilen t testi sonuçları, aşağıdaki tabloda verilmektedir.

Tablo 4. Örgütsel Bağlılık Ölçeği Alt Boyutları Duygusal Devam ve Normatif Bağ lılığın Çalışanların Cinsiyetine Göre Değişimi

\begin{tabular}{rcccc}
\hline Cinsiyet & & $\mathrm{N}$ & Ortalama & Std. Sapma \\
\hline \multirow{2}{*}{ Duygusal Bağlılık } & Kadın & 26 & 3,39 & 0,87 \\
\cline { 2 - 5 } & Erkek & 21 & 3,56 & 0,96 \\
\hline \multirow{2}{*}{ Devam Bağlılığı } & Kadın & 26 & 3,33 & 0,82 \\
\cline { 2 - 5 } & Erkek & 21 & 3,45 & 0,96 \\
\hline \multirow{2}{*}{ Normatif Bağlılık } & Kadın & 26 & 3,40 & 0,93 \\
\cline { 2 - 5 } & Erkek & 21 & 3,19 & 1,00 \\
\hline
\end{tabular}

Gerçekleştirilen t testi sonuçlarına göre kadınların duygusal bağlılık alt boyutu ortalaması 3,39, erkeklerin duygusal bağlılık alt boyutu ortalaması ise 3,56'dır. Böylece erkeklerde duygusal bağlılık alt boyutu ortalaması, kadınlardan daha fazladır. Dolayısıyla ağız ve diş sağlığı merkezinde erkek çalışanlar, kadın çalışanlara oranla kurumlarına karşı daha güçlü duygusal bağlılık hissetmektedirler.

Kadınların devam bağlılığı alt boyutu ortalaması 3,33, erkeklerin ortalaması ise 3,45' dir. Böylece erkeklerde devam bağlılığı alt boyutu ortalaması da kadınlardan daha yüksektir.

Normatif bağlılık alt ortalaması ise kadınlar da 3,40'iken erkeklerde 3,19'dur. $\mathrm{Bu}$ bağlamda kadınlarda normatif bağlılık alt boyutu ortalaması erkeklerden daha yüksektir. Dolayısıyla ağız ve diş sağlığı merkezinde duygusal ve devam bağlılı̆̆1 alt boyutu ortalama değerleri erkeklerde daha yüksekken, normatif bağlılık alt boyutu ortalaması ise kadınlarda daha yüksektir.

Tablo 5. Örgütsel Bağl1lık Ölçeği Alt Boyutları Duygusal Devam ve Normatif Bağlılığın Çalışanların Cinsiyetine Göre Karşılaştırılması için Bağımsız Gruplarda t Testi Sonuçları

\begin{tabular}{|c|c|c|c|c|c|c|c|c|c|c|}
\hline & & \multicolumn{2}{|c|}{$\begin{array}{c}\text { Varyans Eşitlik } \\
\text { Testi }\end{array}$} & \multicolumn{7}{|c|}{ Ortalamaların Eşitliği İçin t Testi } \\
\hline & & \multirow{2}{*}{$\mathrm{F}$} & \multirow[b]{2}{*}{$\mathrm{p}$} & \multirow{2}{*}{$\mathrm{t}$} & \multirow{2}{*}{$\mathrm{sd}$} & \multirow[b]{2}{*}{$\mathrm{p}$} & \multirow{2}{*}{$\begin{array}{l}\text { Ortalama } \\
\text { fark1 }\end{array}$} & \multirow{2}{*}{$\begin{array}{c}\text { Farkın Standart } \\
\text { Hatas1 }\end{array}$} & \multicolumn{2}{|c|}{$\begin{array}{c}\text { \%95 Güven } \\
\text { Aralığ } 1\end{array}$} \\
\hline & & & & & & & & & Alt Sinir & $\begin{array}{c}\text { Üst } \\
\text { Sinır }\end{array}$ \\
\hline \multirow{2}{*}{$\begin{array}{l}\text { Duygusal } \\
\text { Bağll11k }\end{array}$} & Eşit varyans varsayımı & 0,197 & 0,660 & $-0,664$ & 45,000 & 0,510 & $-0,178$ & 0,268 & $-0,717$ & 0,361 \\
\hline & $\begin{array}{l}\text { Eşit olmayan varyans } \\
\text { varsayımı }\end{array}$ & & & $-0,658$ & 41,082 & 0,514 & $-0,178$ & 0,270 & $-0,724$ & 0,368 \\
\hline \multirow[b]{2}{*}{ Devam Bağlılı̆g 1} & Eşit varyans varsayımı & 0,089 & 0,767 & $-0,491$ & 45,000 & 0,626 & $-0,128$ & 0,260 & $-0,651$ & 0,396 \\
\hline & $\begin{array}{l}\text { Eşit olmayan varyans } \\
\text { varsayımı }\end{array}$ & & & $-0,483$ & 39,693 & 0,632 & $-0,128$ & 0,264 & $-0,662$ & 0,407 \\
\hline \multirow{2}{*}{$\begin{array}{l}\text { Normatif } \\
\text { Bağll11k }\end{array}$} & Eşit varyans varsayımı & 0,011 & 0,917 & 0,741 & 45,000 & 0,463 & 0,210 & 0,283 & $-0,360$ & 0,779 \\
\hline & $\begin{array}{l}\text { Eşit olmayan varyans } \\
\text { varsayımı }\end{array}$ & & & 0,735 & 41,382 & 0,467 & 0,210 & 0,285 & $-0,366$ & 0,785 \\
\hline
\end{tabular}

Bağımsız gruplarda $\mathrm{t}$ testi sonuçlarına göre; $\mathrm{p}$ değerleri 05 'ten büyük olduğu için, duygusal ve normatif bağlılık alt boyutları cinsiyete göre anlamlı düzeyde farklılık göstermemektedir (Duygusal bağlılık; $\mathrm{t}=-0,664, \mathrm{p}=0,510$, Devam bağlılı̆̆1; $\mathrm{t}=-0,491, \mathrm{p}=0,626$; Normatif bağl1lık; $\mathrm{t}=0,741, \mathrm{p}=0,463)$. Dolayısıyla araştırmaya katılan tüm cinsiyet gruplarında, tüm örgütsel bağlılık boyutlarına yönelik olumlu algı taşınmaktadır. $\mathrm{Bu}$ nedenle cinsiyet grupları arasında belirgin ve yüksek değerde bir farklılık tespit edilememiştir $\mathrm{t}=0,741, \quad \mathrm{p}=0,463)$. Dolayısıyla araştırmaya katılan tüm cinsiyet gruplarında, tüm örgütsel bağlılık boyutlarına yönelik olumlu algı taşınmaktadır. $\mathrm{Bu}$ nedenle cinsiyet grupları arasında belirgin ve yüksek değerde bir farklılık tespit edilememiştir. 


\subsubsection{Yaş}

Ağız ve diş sağllğı merkezinde örgütsel bağlllık ölçeği alt boyutlarının yaş gruplarına göre ortalamaları ve bu ortalamalar arasındaki farkın anlamlı olup olmadığının tespiti için bağımsız gruplarda yapılan tek yönlü varyans analizi sonuçları aşağıdaki tabloda verilmektedir.

Tablo 6. Örgütsel Bağlılık Ölçeği Alt Boyutları Duygusal Devam ve Normatif Bağl11ığın Çalışanların Yaşına Göre Değișim

\begin{tabular}{|c|c|c|c|c|}
\hline & & $\mathrm{N}$ & Ortalama & Std. Sapma \\
\hline \multirow{6}{*}{ Duygusal Bağlılık } & $20-29$ & 20 & 3,23 & 0,98 \\
\hline & $30-39$ & 16 & 3,49 & 0,77 \\
\hline & $40-49$ & 8 & 3,98 & 0,98 \\
\hline & $50-59$ & 2 & 3,25 & 0,59 \\
\hline & 60 ve üstü & 1 & 4,00 & - \\
\hline & Total & 47 & 3,46 & 0,91 \\
\hline \multirow{6}{*}{ Devam Bağl1llğ 1} & $20-29$ & 20 & 3,56 & 0,97 \\
\hline & $30-39$ & 16 & 3,29 & 0,70 \\
\hline & $40-49$ & 8 & 3,17 & 1,11 \\
\hline & $50-59$ & 2 & 3,09 & 0,59 \\
\hline & 60 ve üstü & 1 & 3,67 & - \\
\hline & Total & 47 & 3,38 & 0,88 \\
\hline \multirow{6}{*}{ Normatif Bağl1lık } & $20-29$ & 20 & 3,28 & 1,10 \\
\hline & $30-39$ & 16 & 3,29 & 0,71 \\
\hline & $40-49$ & 8 & 3,50 & 1,26 \\
\hline & $50-59$ & 2 & 3,00 & 0,28 \\
\hline & 60 ve üstü & 1 & 3,20 & - \\
\hline & Total & 47 & 3,31 & 0,96 \\
\hline
\end{tabular}

Yaş gruplarına göre örgütsel bağlılık ölçeğinin duygusal bağlllık alt boyutu ortalamaları incelendiğinde; $20-29$ yaş grubunun 3,$23 ; 30-39$ yaş grubunun 3,$49 ; 40-49$ yaş grubunun 3,98 olup, 50-59 yaş grubunun $3,25,60$ ve üstü yaş grubunun ise 4,00'dür. Bu bağlamda duygusal bağll11k alt boyutu ortalamasının en yüksek gerçekleştiği yaş grubu 4,00 ortalama ile bir kişinin oluşturduğu 60 ve üstü yaş grubundan sonra 3,98 ortalama değer ile 40-49 yaş grubuna aittir.

Yaş gruplarına göre örgütsel bağlllık ölçeğinin devam bağlılığı alt boyutu ortalamaları incelendiğinde; 20-29 yaş grubunun ortalaması 3,56; 30-39 yaş grubunun ortalaması 3,29 ; 40-49 yaş grubunun ortalaması 3,17 olup, $50-59$ yaş grubunun ortalaması ise 3,09, 60 ve üstü yaş grubunun ise 3,67'dir. Bu bağlamda devam bağlllı̆g alt boyutu ortalamasının en yüksek gerçekleştiği yaş grubu, 3,67 ortalama ile bir kişinin oluşturduğu 60 ve üstü yaş grubundan sonra 3,56 ortalama değer ile 20-29 yaş grubuna aittir.

Normatif bağl1lık alt boyutu ortalamaları ise 20-29 yaş grubunda 3,28, 30-39 yaş grubunda 3,29, 40-49 yaş grubunda $3,50,50-59$ yaş grubunda ise $3,00,60$ ve üstü yaş grubunun ise 3,20 'dir. Normatif bağll lik alt boyutu ortalamasında da en yüksek değer 3,50 ile 40-49 yaş grubu çalışanlarda görülmektedir. Dolayısıyla ağız ve diş sağlığı merkezinde duygusal bağlllık alt boyutunda en yüksek ortalamalar; 60 ve üstü yaş grubu ile $40-49$ yaş grubuna aittir. Devam bağlllığ alt boyutunda ise ortalama değerler en yüksek 60 ve üstü yaş grubu ile 20-29 yaş grubunda gerçekleşmiştir. Normatif bağll lık alt boyutunda ise en yüksek ortalama değer, 40-49 yaş grubunda görülmektedir.
Tablo 7. Örgütsel Bağlılık Ölçeği Alt Boyutları Duygusal Devam ve Normatif Bağlılığın Çalışanların Yaşına Göre Karşılaştırılması İçin Tek Yönlü Varyans Analizi Sonuçları

\begin{tabular}{|c|c|c|c|c|c|}
\hline & & $\begin{array}{c}\text { Kareler } \\
\text { Toplamı }\end{array}$ & $\mathrm{sd}$ & $\begin{array}{c}\text { Ortalama } \\
\text { Kare }\end{array}$ & $\mathrm{p}$ \\
\hline \multirow{3}{*}{$\begin{array}{l}\text { Duygusal } \\
\text { Bağl1lık }\end{array}$} & Grup içi & 3,58 & 4 & 0,89 & $1,100,37$ \\
\hline & Gruplar aras1 & 34,28 & 42 & 0,82 & \\
\hline & Total & 37,86 & 46 & & \\
\hline \multirow{3}{*}{$\begin{array}{l}\text { Devam } \\
\text { Bağlılığ }\end{array}$} & Grup içi & 1,39 & 4 & 0,35 & $0,430,79$ \\
\hline & Gruplar arası & 34,14 & 42 & 0,81 & \\
\hline & Total & 35,53 & 46 & & \\
\hline \multirow{3}{*}{$\begin{array}{l}\text { Normatif } \\
\text { Bağlilık }\end{array}$} & Grup içi & 0,52 & 4 & 0,13 & $0,130,97$ \\
\hline & Gruplar arası & 41,79 & 42 & 0,99 & \\
\hline & Total & 42,31 & 46 & & \\
\hline
\end{tabular}

Tek yönlü varyans analizi sonuçlarına göre duygusal, devam ve normatif bağlılık alt boyutları yaş gruplarına göre $p$ değerleri 05 'ten büyük olduğu için anlamlı düzeyde farklılık göstermemektedir (Duygusal bağlllık; $\mathrm{F}=1,10, \mathrm{p}=0,37$; Devam bağll lı̆ $\mathrm{g} ; \mathrm{F}=0,43, \mathrm{p}=0,79$; Normatif bağll1 lı; $\mathrm{F}=0,13$, $\mathrm{p}=0,97)$. Dolayısıyla araştırmaya katılan tüm yaş grubu işgörenler, tüm örgütsel bağlılık boyutlarına yönelik olumlu algı taşımaktadırlar. $\mathrm{Bu}$ nedenle yaş grupları arasında belirgin ve yüksek değerde bir farkl1lık tespit edilememiştir.

\subsubsection{Medeni Durum}

Ağız ve diş sağlığı merkezi'nde örgütsel bağlılık ölçeği alt boyutlarının, medeni duruma göre ortalamaları ve bu ortalamalar arasındaki farkın anlamlı olup olmadığının tespiti için yapılan bağımsız gruplarda $t$ testi sonuçları aşağıdaki tabloda verilmektedir.

Tablo 8. Örgütsel Bağlılık Ölçeği Alt Boyutları Duygusal Devam ve Normatif Bağlılığın Çalışanların Medeni Durumuna Göre Değişimi

\begin{tabular}{lllcc}
\hline Medeni durum & & $\mathrm{N}$ & Ortalama & Std. Sapma \\
\hline \multirow{2}{*}{ Duygusal Bağlılık } & Evli & 27 & 3,63 & 0,91 \\
\cline { 2 - 5 } & Bekar & 20 & 3,24 & 0,88 \\
\hline \multirow{2}{*}{ Devam Bağlılığı } & Evli & 27 & 3,39 & 0,78 \\
\cline { 2 - 5 } & Bekar & 20 & 3,37 & 1,01 \\
\hline \multirow{2}{*}{ Normatif Bağlılık } & Evli & 27 & 3,47 & 0,82 \\
\cline { 2 - 5 } & Bekar & 20 & 3,08 & 1,10 \\
\hline
\end{tabular}

Evli olanların duygusal bağlılık alt boyutu ortalaması 3,63, bekarların ise 3,24'dür. Bu bağlamda örgütsel bağlılık ölçeği duygusal bağlılık alt boyutu ortalaması 3,63 değeri ile evli olanlarda bekarlardan daha yüksektir. Evli olanların devam bağlılığ1 alt boyutu ortalaması 3,39 olup bekar olanların ortalamas1 ise 3,37'dir. Benzer şekilde evlilerde devam bağlılığ1 alt boyutu ortalaması, bekarlardan daha yüksektir. Normatif bağlılık alt boyutu ortalaması ise evlilerde 3,47'iken, bekarlarda 3,08'dir. Dolayısıyla normatif bağlılık alt boyutu ortalaması, diğer iki bağlılık alt boyutunda olduğu gibi evlilerde bekarlardan daha yüksek tespit edilmiştir. Sonuçta üç bağlılık alt boyutunda da evlilerin ortalamalarının bekarlardan daha yüksek olması dikkat çekmektedir. 
Tablo 9. Örgütsel Bağlılık Ölçeği Alt Boyutları Duygusal Devam ve Normatif Bağlılığın Çalışanların Medeni Durumuna Göre Karşılaştırılması için t Testi Sonuçları

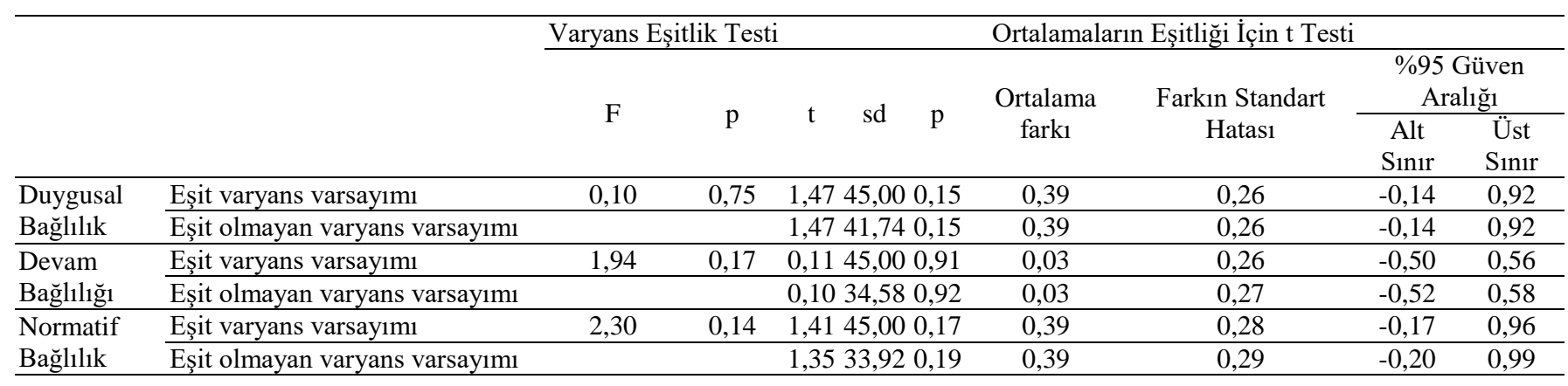

Bağımsız gruplarda t testi sonuçlarına göre; örgütsel bağlılık ölçeğinin duygusal, devam ve normatif bağlilık alt boyutlarının $\mathrm{p}$ değerleri 05 'ten büyük olduğu için medeni duruma göre anlamlı düzeyde farklılık göstermemektedir (Duygusal bağlılık; $\mathrm{t}=1,47, \mathrm{p}=0,15$; Devam bağlılığ $1 ; \mathrm{t}=0,11$, $\mathrm{p}=0,91$; Normatif bağlılık; $\mathrm{t}=1,41, \mathrm{p}=0,17)$. Dolayısıyla araştırmaya katılan tüm medeni durum grubu işgörenler, tüm örgütsel bağlılık boyutlarına yönelik olumlu algı taşımaktadırlar. $\mathrm{Bu}$ nedenle tüm medeni durum grupları arasında belirgin ve yüksek değerde bir farklılık tespit edilememiştir.

\subsection{4. Ĕgitim Seviyesi}

Ağız ve diş sağlığı merkezinde örgütsel bağlılık ölçeği alt boyutlarının, eğitim seviyesine göre ortalamaları ve bu ortalamalar arasındaki farkın anlamlı olup olmadığının tespiti için tek yönlü varyans analizi uygulanmıştır. Gerçekleştirilen tek yönlü varyans analizi sonuçları aşağıdaki tabloda verilmektedir.

Tablo 10. Örgütsel Bağlılık Ölçeği Alt Boyutları Duygusal Devam ve Normatif Bağlılığın Çalışanların Eğitim Durumuna Göre Değişimi

\begin{tabular}{|c|c|c|c|c|}
\hline & & $\mathrm{N}$ & Ortalama & Std. Sapma \\
\hline \multirow{6}{*}{ Duygusal Bağlılık } & İlköğretim & 1 & 4,67 & - \\
\hline & Lise & 8 & 4,17 & 1,00 \\
\hline & Ön Lisans & 11 & 3,24 & 0,75 \\
\hline & Lisans & 14 & 3,63 & 0,67 \\
\hline & Yüksek Lisans & 13 & 2,95 & 0,90 \\
\hline & Total & 47 & 3,46 & 0,91 \\
\hline \multirow{6}{*}{ Devam Bağl1lığ1 } & İlköğretim & 1 & 3,33 & - \\
\hline & Lise & 8 & 3,79 & 0,98 \\
\hline & Ön Lisans & 11 & 3,59 & 0,66 \\
\hline & Lisans & 14 & 3,73 & 0,58 \\
\hline & Yüksek Lisans & 13 & 2,59 & 0,83 \\
\hline & Total & 47 & 3,38 & 0,88 \\
\hline \multirow{6}{*}{ Normatif Bağlllık } & İlköğretim & 1 & 4,40 & - \\
\hline & Lise & 8 & 3,88 & 1,04 \\
\hline & Ön Lisans & 11 & 3,33 & 0,91 \\
\hline & Lisans & 14 & 3,56 & 0,61 \\
\hline & Yüksek Lisans & 13 & 2,58 & 0,92 \\
\hline & Total & 47 & 3,31 & 0,96 \\
\hline
\end{tabular}

Örgütsel bağlılık ölçeği alt boyutlarının eğitim düzeyine göre ortalamaları ve bu ortalamalar arasındaki farkın anlamlı olup olmadığının tespiti için yapılan tek yönlü varyans analizi sonuçları yukarıda verilmektedir. Buna göre İlköğretim mezunlarının duygusal bağlılık alt boyutu ortalaması 4,67, lise mezunlarının 4,17, ön lisans mezunlarının 3,24'iken lisans mezunlarının 3,63, yüksek lisans mezunlarının ise 2,95'dir. Bu bağlamda örgütsel bağlılık ölçeği duygusal bağlılık alt boyutu ortalaması en yüksek 4,67 değeri ile bir çalışanın oluşturduğu ilköğretim mezunları grubundan sonra 4,17 ortalama ile lise mezunlarında gerçekleşmiştir.

Yukarıdaki tablodan görüldüğü üzere İlköğretim mezunlarının devam bağlılığı alt boyutu ortalaması 3,33, lise mezunlarının 3,79, ön lisans mezunlarının 3,59, lisans mezunlarının 3,73, yüksek lisans mezunlarının ise 2,59'dur. Bu bağlamda örgütsel bağlılık ölçeği devam bağlılığı alt boyutu ortalaması 3,79 değeri ile en yüksek lise mezunlarında görülmektedir.

Normatif bağlılık alt boyutu ortalaması ise ilköğretim mezunlarında 4,40, lise mezunlarında 3,88, ön lisans mezunlarında 3,33, lisans mezunlarında 3,56, yüksek lisans mezunlarının 2,58'dir. Böylelikle normatif bağlılık alt boyutu ortalaması en yüksek 4,40 değeri ile bir çalışanın oluşturduğu ilköğretim mezunları grubundan sonra 3,88 ortalama ile lise mezunlarına aittir. Sonuçta duygusal ve normatif bağlılık alt boyutlarında en yüksek ortalamalar; ilköğretim ve lise mezunlarında gerçekleşirken, devam bağlılığ1 alt boyutunda ise en yüksek ortalama, sadece lise mezunlarında görülmektedir.

Tablo 11. Örgütsel Bağlılık Ölçeği Alt Boyutları Duygusal Devam ve Normatif Bağlılığın Çalışanların Eğitim Durumuna Göre Karşılaştırılması için Tek Yönlü Varyans Analizi Sonuçları

\begin{tabular}{|c|c|c|c|c|c|c|}
\hline & & $\begin{array}{c}\text { Kareler } \\
\text { Toplamı }\end{array}$ & sd & $\begin{array}{c}\text { Ortalama } \\
\text { Kare }\end{array}$ & $\mathrm{F}$ & $\mathrm{p}$ \\
\hline \multirow{3}{*}{$\begin{array}{l}\text { Duygusal } \\
\text { Bağlilık }\end{array}$} & Grup içi & 9,789 & 4 & 2,447 & \multicolumn{2}{|c|}{$3,6620,012^{*}$} \\
\hline & Gruplar arası & 28,071 & 42 &, 668 & & \\
\hline & Total & 37,860 & 46 & & & \\
\hline \multirow{3}{*}{$\begin{array}{l}\text { Devam } \\
\text { Bağl1lı̆g1 }\end{array}$} & Grup içi & 11,654 & 4 & 2,913 & \multicolumn{2}{|c|}{$5,1240,002 *$} \\
\hline & Gruplar arası & 23,878 & 42 &, 569 & & \\
\hline & Total & 35,532 & 46 & & & \\
\hline \multirow{3}{*}{$\begin{array}{l}\text { Normatif } \\
\text { Bağlılık }\end{array}$} & Grup içi & 11,440 & 4 & 2,860 & \multicolumn{2}{|c|}{$3,8910,009 *$} \\
\hline & Gruplar arası & 30,868 & 42 & ,735 & & \\
\hline & Total & 42,308 & 46 & & & \\
\hline
\end{tabular}

Tek yönlü varyans analizi sonucuna göre örgütsel bağlılı̆̆ın duygusal, devam ve normatif bağlılık alt boyutları, eğitim durumuna göre p değerleri 05 'ten küçük olduğu için anlamlı düzeyde farklılık göstermektedir (Duygusal bağlılık: $\mathrm{F}=3,662 ; \mathrm{p}=0,012 ;$ Devam bağlılı̆̆1: $\mathrm{F}=5,124 ; \mathrm{p}=0,002$; Normatif bağlılık: $F=3,891 ; p=0,009)$

Dolayısıyla örgütsel bağlılık tüm alt boyutları ile eğitim grupları arasında belirgin bir farklılık bulunmaktadır Farklılığın hangi gruptan kaynaklandığını tespit etmek 
amacıyla yapılan TUKEY testi sonuçları aşağıdaki tabloda verilmektedir.

Tablo 12. Örgütsel Bağlılık Boyutlarının Çalışanların Eğitim Durumuna Göre Karşılaştırılması İçin Tukey Testi Sonuçları

\begin{tabular}{|c|c|c|c|c|c|c|c|}
\hline & & & Ortalama & Std. & & $\begin{array}{r}\% 95 \\
\text { Ara } \\
\end{array}$ & $\begin{array}{l}\text { Güven } \\
\operatorname{li}_{1} \breve{g}_{1}\end{array}$ \\
\hline & & & Fark1 & Hata & $\mathrm{p}$ & $\begin{array}{c}\text { Alt } \\
\text { Sinir }\end{array}$ & $\begin{array}{c}\text { Üst } \\
\text { Sinır }\end{array}$ \\
\hline & & $\begin{array}{l}\text { Ön } \\
\text { Lisans }\end{array}$ & 0,92 & 0,38 & 0,09 & $-0,09$ & 1,94 \\
\hline & Lise & Lisans & 0,53 & 0,36 & 0,46 & $5-0,44$ & 1,50 \\
\hline & & $\begin{array}{l}\text { Yüksek } \\
\text { Lisans } \\
\end{array}$ & $1,21^{*}$ & 0,37 & 0,01 & $1 \quad 0,24$ & 2,20 \\
\hline & & Lise & $-0,92$ & 0,38 & 0,09 & $-1,94$ & 0,09 \\
\hline & Ön & Lisans & $-0,39$ & 0,33 & 0,64 & $7-1,27$ & 0,49 \\
\hline Duygusal & Lisans & $\begin{array}{l}\text { Yüksek } \\
\text { Lisans }\end{array}$ & 0,29 & 0,33 & 0,82 & $2-0,60$ & 1,19 \\
\hline Bağlılık & & Lise & $-0,53$ & 0,36 & 0,46 & $5-1,50$ & 0,44 \\
\hline & Lisans & $\begin{array}{l}\text { Ön } \\
\text { Lisans }\end{array}$ & 0,39 & 0,33 & 0,64 & $4-0,49$ & 1,27 \\
\hline & & $\begin{array}{l}\text { Yüksek } \\
\text { Lisans }\end{array}$ & 0,68 & 0,31 & 0,15 & $5-0,16$ & 1,53 \\
\hline & & Lise & $-1,21^{*}$ & 0,37 & 0,01 & $-2,20$ & $-0,24$ \\
\hline & $\begin{array}{l}\text { Yüksek } \\
\text { Lisans }\end{array}$ & $\begin{array}{l}\text { Ön } \\
\text { Lisans }\end{array}$ & $-0,29$ & 0,33 & 0,82 & $2-1,19$ & 0,60 \\
\hline & & Lisans & $-0,68$ & 0,31 & 0,15 & $-1,53$ & 0,16 \\
\hline & & $\begin{array}{l}\text { Ön } \\
\text { Lisans }\end{array}$ & 0,20 & 0,35 & 0,94 & $4-0,74$ & 1,14 \\
\hline & Lise & Lisans & 0,06 & 0,33 & 1,00 & $-0,83$ & 0,96 \\
\hline & & $\begin{array}{l}\text { Yüksek } \\
\text { Lisans }\end{array}$ & $1,20^{*}$ & 0,34 & 0,01 & 0,30 & 2,11 \\
\hline & & Lise & $-0,20$ & 0,35 & 0,94 & $4-1,14$ & 0,74 \\
\hline & Ön & Lisans & $-0,14$ & 0,30 & 0,97 & $7-0,95$ & 0,68 \\
\hline Devam & Lisans & $\begin{array}{l}\text { Yüksek } \\
\text { Lisans }\end{array}$ & $1,00^{*}$ & 0,31 & 0,01 & 0,18 & 1,83 \\
\hline Bağlılığ1 & & Lise & $-0,06$ & 0,33 & 1,00 & $-0,96$ & 0,83 \\
\hline & Lisans & $\begin{array}{l}\text { Ön } \\
\text { Lisans }\end{array}$ & 0,14 & 0,30 & 0,97 & $7-0,68$ & 0,95 \\
\hline & & $\begin{array}{l}\text { Yüksek } \\
\text { Lisans }\end{array}$ & $1,13^{*}$ & 0,29 & 0,00 & 0,36 & 1,91 \\
\hline & & Lise & $-1,20^{*}$ & 0,34 & 0,01 & $-2,11$ & $-0,30$ \\
\hline & $\begin{array}{l}\text { Yüksek } \\
\text { Lisans }\end{array}$ & $\begin{array}{l}\text { Ön } \\
\text { Lisans }\end{array}$ & $-1,00^{*}$ & 0,31 & 0,01 & $1-1,83$ & $-0,18$ \\
\hline & & Lisans & $-1,13^{*}$ & 0,29 & 0,00 & $-1,91$ & $-0,36$ \\
\hline & & $\begin{array}{l}\text { Ön } \\
\text { Lisans }\end{array}$ & 0,55 & 0,40 & 0,52 & $-0,52$ & 1,61 \\
\hline & Lise & Lisans & 0,32 & 0,38 & 0,84 & $4-0,70$ & 1,33 \\
\hline & & $\begin{array}{l}\text { Yüksek } \\
\text { Lisans }\end{array}$ & $1,29^{*}$ & 0,39 & 0,01 & 0,26 & 2,32 \\
\hline & & Lise & $-0,55$ & 0,40 & 0,52 & $2-1,61$ & 0,52 \\
\hline & Ön & Lisans & $-0,23$ & 0,35 & 0,91 & $-1,15$ & 0,69 \\
\hline Normatif & Lisans & $\begin{array}{l}\text { Yüksek } \\
\text { Lisans }\end{array}$ & 0,74 & 0,35 & 0,17 & $7-0,20$ & 1,68 \\
\hline Bağlılık & & Lise & $-0,32$ & 0,38 & 0,84 & $4-1,33$ & 0,70 \\
\hline & Lisans & $\begin{array}{l}\text { Ön } \\
\text { Lisans } \\
\end{array}$ & 0,23 & 0,35 & 0,91 & $1-0,69$ & 1,15 \\
\hline & & $\begin{array}{l}\text { Yüksek } \\
\text { Lisans }\end{array}$ & $0,97^{*}$ & 0,33 & 0,03 & 30,09 & 1,86 \\
\hline & & Lise & $-1,29^{*}$ & 0,39 & 0,01 & $-2,32$ & $-0,26$ \\
\hline & $\begin{array}{l}\text { Yüksek } \\
\text { Lisans }\end{array}$ & $\begin{array}{l}\text { Ön } \\
\text { Lisans }\end{array}$ & $-0,74$ & 0,35 & 0,17 & $7-1,68$ & 0,20 \\
\hline & & Lisans & $0-, 97^{*}$ & 0,33 & 0,03 & $3-1,86$ & $-0,09$ \\
\hline
\end{tabular}

Tukey testi sonuçlarına göre; duygusal bağlılık için; lise mezunlarının ortalaması, yüksek lisans mezunlarının ortalamasından anlamlı derecede daha büyüktür. Diğer eğitim düzeyine sahip kişilerin ortalamaları arasında anlamlı düzeyde farklılık bulunmamaktadır.

Devam bağlılı̆̆ ortalamas1, diğer tüm gruplardan anlamlı derecede daha küçüktür.

Normatif bağlılık için; lise ve lisans mezunu kişilerin ortalaması, yüksek lisans mezunu kişilerin ortalamasından anlamlı derecede daha büyüktür. Lise ve lisans mezunu kişilerin ortalamaları arasında ise anlamlı düzeyde farklılık bulunmamaktadır.

\section{Sonuç}

15.08.2017 tarih ve 694 sayılı KHK ile Sağlık Bakanlığı Teşkilatı'nda gerçekleştirilen yapısal değişikliklerin sonucunda örgütsel bağlılığın, sağlık kurum ve kuruluşlarında ortaya hangi sonuçlar koyacağının belirlenebilmesi açısından örgütsel bağlılığın analiz edilmesinin büyük önemi bulunmaktadır. Bu amaçla, bu çalışmada ağız ve diş sağlığı merkezinde görev yapmakta olan çalışanlar nezdinde, örgütsel bağl1lık anketinin uygulaması gerçekleştirilmiştir. Çalışmada örgütsel bağlılık ölçeği maddeleri, maddelerin taşıdıkları nitelik gereği duygusal, devam ve normatif bağlılık boyutları olmak üzere üç boyutta analiz edilmekte ve değerlendirilmektedir. Çalışmada elde edilen bulgular, kapsamlı olarak çalışmanın metodoloji kısmında değerlendirilmektedir. Aşağıda ise çalışmanın hipotezleri ekseninde özet bir değerlendirme sunulmaktadir.

Ağız ve diş sağlığı merkezinde uygulanan anket sonrasında; örgütsel bağlılık ölçeğinin duygusal bağlılık alt boyutu 1-5 aralığında 3,46 seviyesinde, devam bağlılığ1 alt boyutu 3,38 seviyesinde, normatif bağl1lık alt boyutu ortalaması ise 3,31 seviyesinde gerçekleşmiştir. Buna göre ağız ve diş sağlığı merkezi genelinde örgütsel bağlılığın daha çok duygusal bağlılık boyutunda geliştiği anlaşılmaktadır. Duygusal bağl1lık, işgörenlerin tüm benlikleriyle örgütlerini özdeşleştirmeleri ve kendilerini örgütlerine adama düşüncesiyle gelişen bir bağlılık boyutudur. Bu kapsamda duygusal bağlılık, örgütler için büyük önem taşımaktadır. Çünkü örgütlerin, amaçlarını daha hızlı ve kolay gerçekleştirebilmelerinde, misyonlarını başarıyla yerine getirebilmelerinde kendilerine en büyük katkıyı sağlayacak bağlılık boyutunun, duygusal bağlılık olduğu söylenebilir. Dolayısıyla ağız ve diş sağlığı merkezinde görev yapan çalışanlar nezdinde en yüksek oranda duygusal bağlılığın gelişmiş olması önemli ve kurumsal bağlamda arzu edilen bir sonucu ifade etmektedir. En az özel sektör kadar kamu kurum ve kuruluşlarında da önem taşıyan örgütsel bağlılığın, ağız ve diş sağlığı merkezinde duygusal bağlılık boyutunda daha fazla gelişmiş olması, kamunun sunduğu hizmet standartlarının yükselmesi ve niteliğinin geliştirilmesi yönünden son derece olumlu bir gelişmedir. Fakat bu sonuç yeterli görülmemeli, söz konusu 3,46'lık duygusal bağlılık ortalamasının daha da geliştirilmesi için çalışmalara ve uygulamalara ağırlık verilmelidir. Çalışmanın hipotezleri ekseninde elde edilen bulgulara aşağıda kısaca değinilmektedir.

Ağı ve diş sağlığı merkezinde cinsiyet grupları arasında; erkek çalışanlar, 3,56 ortalama değer ile kadın çalışanlara oranla kurumlarına karşı daha güçlü duygusal bağlılık hissetmektedirler. Erkeklerde benzer şekilde 3,45 ortalama 
ile devam bağlılığı, kadınlardan daha yüksek gerçekleşmiştir. Normatif bağlılıkta ise 3,40 ortalama ile kadınlarda, erkeklerden daha yüksek bir ortalama söz konusudur. Dolayısıyla ağız ve diş sağlığı merkezinde duygusal ve devam bağlılığ 1 alt boyutlarında ortalama değerler, erkek çalışanlarda daha yüksekken, kadın çalışanlarda normatif bağlılık alt boyutu ortalaması, erkek çalışanlardan daha yüksek gerçekleşmiştir.

Ağız ve diş sağlı̆̆ı merkezinde yaş grupları arasında; duygusal bağlılık alt boyutu ortalamasının en yüksek gerçekleştiği yaş grubu, 4,00 ortalama ile bir kişinin oluşturduğu 60 ve üstü yaş grubundan sonra 3,98 ortalama değer ile 40-49 yaş grubuna aittir. Devam bağlılığı alt boyutu ortalamasının en yüksek gerçekleştiği yaş grubu, 3,67 ortalama ile bir kişinin oluşturduğu 60 ve üstü yaş grubundan sonra 3,56 ortalama değer ile 20-29 yaş grubuna aittir. Normatif bağlılık alt boyutu ortalamasında ise en yüksek değer 3,50 ile 40-49 yaş grubu çalışanlarda görülmektedir. Dolayısıyla ağız ve diş sağlığı merkezinde duygusal bağlılık alt boyutunda en yüksek ortalamalar; 60 ve üstü yaş grubu ile 40-49 yaş grubuna aittir. Devam bağlılığı alt boyutunda ise ortalama değerler en yüksek 60 ve üstü yaş grubu ile 2029 yaş grubunda gerçekleşmiştir. Normatif bağlılık alt boyutunda ise en yüksek ortalama değer, 40-49 yaş grubunda görülmektedir.

Ağı ve diş sağlığı merkezinde medeni durum grupları arasında; örgütsel bağlılık ölçeği duygusal bağlılık alt boyutu ortalaması 3,63 değeri ile evli olanlarda bekarlardan daha yüksektir. Evli olanların devam bağlılığı alt boyutu ortalamas1 3,39 olup bekar olanların ortalamas1 ise 3,37'dir. Benzer şekilde evlilerde devam bağlılığ ortalaması, bekarlardan daha yüksektir. Normatif bağlılık alt boyutu ortalamas1 ise evlilerde 3,47'iken, bekarlarda 3,08'dir. Dolayısıyla normatif bağl1lık alt boyutu ortalamas1, diğer iki bağlılık alt boyutunda olduğu gibi evlilerde bekarlardan daha yüksek tespit edilmiştir. Sonuçta üç bağlılık alt boyutunda da evlilerin ortalamalarının bekarlardan daha yüksek olması dikkat çekmektedir.

Ağız ve diş sağlığı merkezinde eğitim seviyesi grupları arasında; duygusal bağlılık alt boyutu ortalaması en yüksek 4,67 değeri ile bir çalışanın oluşturduğu ilköğretim mezunları grubundan sonra 4,17 ortalama ile lise mezunlarında gerçekleşmiştir. Örgütsel bağlılık ölçeği devam bağlılı̆̆ alt boyutu ortalaması 3,79 değeri ile en yüksek lise mezunlarında görülmektedir. Normatif bağlılık alt boyutu ortalaması ise en yüksek 4,40 değeri ile bir çalışanın oluşturduğu ilköğretim mezunları grubundan sonra 3,88 ortalama ile lise mezunlarına aittir. Sonuçta duygusal ve normatif bağlılık alt boyutlarında en yüksek ortalamalar; ilköğretim ve lise mezunlarında gerçekleşirken, devam bağlılığ1 alt boyutunda ise en yüksek ortalama sadece lise mezunlarında görülmektedir.

\section{Kaynakça}

Aktay, D. D. (2010). Işs tatmini ve örgütsel bă̆lllık arasındaki ilişki ve askeri hastanede bir uygulama. Yüksek Lisans Tezi. İstanbul: İstanbul Üniversitesi.

Durukan, S., Akyürek, Ç., \& Coşkun, E. (2010). Hacettepe Üniversitesi Erişkin Hastanesi’nde Çalışan Hemşirelerin Örgütsel Güven, Güçlendirme ve Bağlılık Düzeylerinin
Belirlenmesi. Süleyman Demirel Üniversitesi İktisadi ve Idari Bilimler Fakültesi Dergisi, 15(3), 411-434.

İnce, H., \& Gül, M. (2005). Yönetimde yeni bir paradigma: örgütsel bağlılık. Konya: Çizgi Kitabevi Yayınları.

Kanter, R. M. (1968). Commitment and Social Organizations. American Sociological Review, 33, 449517.

Karahan, A. (2008). Hastanelerde Liderlik ve Örgütsel Bağlılık Arasındaki İlişkinin İncelenmesi. Afyon Kocatepe Üniversitesi Sosyal Bilimler Dergisi, 145-162.

Meyer, J. P., \& Allen, N. J. (1991). A Three Component Conceptualization of Organizational Commitment. Human Resources Management Review, 1, 61-89.

Meyer, J.P., \& Allen, N.J. (1997). Commitment in the work place; theory, research, and application. Sage, Thousand Oaks, Ca.

Mowday, R. T., Steers R. M., \& Porter L. W. (1979). The Measurement of Organizational Commitment. Journal of Vocational Behavior, 14, 227-247.

Obeng, K., \& Ugboro, I. (2003). Organizational Commitment Among Public Transit Employees: An Assessment Study. Journal of The Transportation Research Forum, 57(2), 83-98.

Resmi Gazete (1983). Yataklı Tedavi Kurumları İşletme Yönetmeliği. 13.01.1983 tarih ve Sayı : 17927.

Resmi Gazete (2017). 15.08.2017 tarih ve 694 sayll Kanun Hükmünde Kararname. 25.08.2017 tarih ve Sayı: 30165.

Wahn, J. C. (1998). Sex Differences In The Continuance Component or Organization Commitment. Group \& Organizational Management, 23(3), 256-268.

Yıldız, K. (2013). Örgütsel Bağl1lık ile Örgütsel Sinizm ve Örgütsel Muhalefet Arasındaki İlişki. International Periodical For the Languages, Literature and History of Turkish or Turkic, 8(6), 853-879.

Yüceler, A. (2009). Örgütsel Bağlılık ve Örgüt İklimi İlişkisi: Teorik ve Uygulamalı Bir Çalışma. Selçuk Üniversitesi Sosyal Bilimler Enstitüsü Dergisi, 22, 4.-26. 